Print ISSN: 2288-4637 / Online ISSN 2288-4645

doi:10.13106/jafeb.2019.vol6.no3.123

\title{
Effects of Foreign Direct Investment and Human Capital on Labour Productivity: Evidence from Vietnam
}

\author{
Nguyen Hoang LE ${ }^{1}$, Luong Vinh Quoc DUY', Bui Hoang NGOC ${ }^{3}$
}

Received: May 26, 2019 Revised: May 27, 2019 Accepted: June 14, 2019

\begin{abstract}
The paper aims to investigate whether foreign direct investment (FDI) has positive effect on the labour productivity in Vietnam. Labour productivity is the elemental determinant of a country's development level in long-term. In recent years, although increasing consistently, labour productivity of Vietnam remains low in comparison to other South East Asian countries. To identify the direction of effect and the level of effect of FDI and human capital on the labour productivity of Vietnam, Autoregressive Distributed Lag (ARDL) model was used to examine the effect of FDI and human capital on labour productivity in Vietnam from 1986 to 2014. The results of bounds test confirm the existence of cointegration among the variables. Further, the Toda and Yamamoto Granger causality test affirms that there is unidirectional causality running from foreign direct investment and human capital index to labour productivity. The empirical results provide strong statistical evidence that foreign direct investment and human capital has a positive impact on labour productivity in Vietnam in long-term. These findings imply that workers are expected to further improve their knowledge, skills and that policy-maker should establish concrete plans to increase human capital. Results from this study provide suggestion necessary for Vietnam to achieve sustainable development.
\end{abstract}

Keyword: Labour Productivity, Human Capital, Foreign Direct Investment, ARDL, Vietnam.

JEL Classification Code: O14, O30, Q47, Q53.

\section{Introduction}

The 21's century is an era of knowledge economy with creative economy at central. Science and technology have become productive forces of the society. In underdeveloped and developing countries, there has been increasing need for nationwide improvement of labour productivity and quality of products. Based on success stories of Korea, Taiwan, and Singapore, innovation and creativity is a key to success, a factor to improve labour productivity, and an engine for growth.

1 First Author. Dean, Institute of Human Resources Development Research, University of Economics Ho Chi Minh City, Vietnam. Email: hoangle@ueh.edu.vn

2 Lecturer, School of Economics, University of Economics Ho Chi Minh City, Vietnam. Email: quocduy@ueh.edu.vn

3 Corresponding Author. Ph.D. Candidate, Graduate School, Ho Chi Minh City Open University, Vietnam [Postal Address: 97 Vo Van Tan Street, District.3, Ho Chi Minh City, 700000, Vietnam] Email: ngocbh.16ae@ou.edu.vn

() Copyright: Korean Distribution Science Association (KODISA)

This is an Open Access article distributed Creative Commons Attribution NonCommercial License (https://creativecommons.org/licenses/by-nc/4.0/) which permits unrestricted noncommercial use, distribution, and reproduction in any medium, provided the original work is properly cited.
Labour productivity is the amount of goods and services produced by a worker during a certain period of time. According to Romer $(1986,1990)$ there were 4 main sources of economic growth, including: "resource", "capital", "technology" and "labor". Importantly, the potential of "labor" capital was unlimited as explained in the "learning by doing" model of Arrow (1962). There might be no distinct levels of improvement, yet the productivity of workers could be increased in a short term or a long term, through any lesson learned from mistakes and any valuable experience, or thanks to their ability to learn by themselves.

The relationship between foreign direct investment (FDI) and labour productivity of domestic enterprises were unveiled in many studies. Caves (1996) and Blomstrom and Kokko (1998) claimed that FDI not only brought capital to the recipient country, but also acted as an incentive for enterprises to promote investments, transfer of technology and brand names, etc. Domestic enterprises were found to be positively affected by forward and backward linkages in following ways: (i) export promotion (Egger \& Pfaffermayr, 2001); (ii) transfer of advances in production (Javorcik, 2004); and (iii) improvement of product quality (Krueger \& Lindahl, 2001; Schoors \& Van der Tol, 2001). In contrast, 
Engelbrecht $(1997,2002)$ suggested that the effect of FDI at the industrial level was neutral and unclear as the investors attracted to invest in a country might not necessarily adopt advanced technology. Hale and Long (2011) argued that the spillovers of FDI to domestic enterprises were greatly affected by institutions. Clearly, these effects are of little evidence if the gap in technology of the two sides is too large or the number of professional workers is not sufficient.

According to a report release on May 9th, 2014 of the International Labour Office (ILO) shows that labour productivity of Vietnam is in the lowest group in the AsiaPacific. Labour productivity of Singapore, Japan and Korea, Malaysia and Thailand are higher than that of Vietnam respectively by $15,11,10,5$ and 2.5 times. Economists have pointed out that countries with economic growth driven by unstable sources such as natural resources, outdated technology and low-cost labour are unlikely to achieve sustainable development. If workers do not receive adequate training, their skills will be able to meet the requirements of modern technology. As a result, despite investment in technology, that country is still on a downward spiral without any sign of development. The development of all countries are affected by powerful, complex and interrelated factors, leading to unpredictable and even devastating outcomes. Given rapid advances of science and technology in Vietnam, never has there been such an urgent need for improving labour productivity.

Domestic enterprises need to survive in the competition with multinational enterprises (MNEs) before making use of advantages of FDI. Markusen and Venables (1999) and Aitken and Harison (1999) indicated that domestic enterprises might be driven out of the market due to the market-stealing effect of MNEs and joint venture enterprises. Three possible reasons for that effect were explained as: $(i)$ MNEs had better product quality and lower cost of production thanks to more advanced technology; (ii) the superior capital size and management of MNEs ensured advantages in price competition; (iii) MNEs were often offered with favourable geographical locations and tax policies by government.

Vietnam, a country transforming from an agricultural economy, is characterised with relatively low capital stock, low level of production and low intellectual standard. This paper aims at investigating whether FDI has positive effect on the labour productivity in Vietnam. Results from this study provide suggestion necessary for Vietnam to achieve sustainable development.

\section{Literature Review}

According to Nowbutsing (2009), the effect of FDI on economic growth could be decomposed into three main groups of factors: (i) the direct effect; (ii) the indirect effect; and (iii) the reverse effect.

The direct effect is shown direct effect of FDI on growth. The production function $Q=f(L, K)$ implies that FDI directly causes output through accumulation of tangible assets (or increase in K). The direct effect of FDI was explained using the neoclassical model. However, identifying the direct effect only gave a partial understanding of the FDI - Growth connection. Thus, it was important to see beyond the direct effect of FDI. The new growth theories were examined to prove the importance of the indirect effect with respect to FDI.

The indirect effect is shown indirect effect from FDI to growth. The term "spillovers" implies the positive interrelations between four effect channels. Four main channels of FDI spillovers, which are: competition, linkages, skills and imitation. As an implication, the total spillovers created by FDI, was assumed to depend on the absorption capacity. Absorption capacity is measured through the ability of a country to generate and/or absorb the spillover effects of FDI. Absorption capacity was determined by conditional factors.

Finally, the reverse effect was believed to occur if economic growth led to an increase of FDI. The existence of reverse effect has been shown by studies on the causality between FDI and economic growth (Choe, 2003; Chakraborty \& Basu, 2002).

\subsection{The Relationship between FDI and Labour Productivity}

The AK growth model, created by Harrod (1939) and Domar (1946) and developed by Frankel (1962) and Romer and Frankel (1999), explains accelerated FDI inflows to many developing countries. They believed that capital accumulation from FDI might not be accompanied by a drop in marginal profit. Profits of domestic enterprises might be boosted due to external factors derived from FDI such as technology, new administrative techniques and knowledgesharing effect. Hence, the AK model implies that countries should continue attracting FDI, as in enterprises, more capital can be gained from issuing shares and labour productivity can also be boosted. In other words, with access to FDI, enterprises are likely introduced to advanced administrative technology that may be adopted to increase labor productivity, thereby contributing to both short-term and long-term economic development of the country.

The spillovers of FDI to productivity of domestic enterprises are identified through two channels: horizontal spillovers and vertical spillovers. Horizontal spillovers refer to intra-industry effects of FDI on domestic enterprises. 
Blomstrom and Wang (1992) and Blomstrom and Kokko (1998) suggested that these effects were shown in many aspects such as imitation of technology and administrative skills, mobility of professional labour, competition, redistribution of market... Meanwhile, vertical spillovers are associated with the chain of MNEs and enterprises in supporting industries in a country. Vertical spillovers are shown through forward linkages. In this relationship, MNEs act as suppliers, domestic enterprises are customers. For backward linkages, domestic enterprises act as suppliers, whilst MNEs are customers.

Through forward linkage, domestic enterprises are provided with higher quality goods and services at a lower price by MNEs. Thanks to superior management, marketing and administrative innovation, domestic enterprise might be provided with advanced sales and administrative technology. Regarding backward linkage, established international customers and provider networks of MNEs offer domestic enterprises with opportunities to expand exports and join international supply chains. Technology transfer, technical assistance, labour training and credit support, etc. are some of benefits brought to domestic enterprises through backward linkages.

In summary of empirical research, the effect of FDI on labour productivity of domestic enterprises was decomposed into three types of effects: (i) positive effect; (ii) mixed effect; and (iii) no effect. As indicated by some empirical studies, positive effects of MNEs on domestic enterprises include transfer of advanced technology, strengthened competitiveness, improved forces of production, better labour skills, and an inflow of skilled workers. These conclusions can be found in research of Javorcik (2004) for Lithuania; Globerman and Steven (1979) for Canada; Caves (1971) for Australia. Monastiriotis and Alegria (2011) discovered positive effects of Greek and European enterprises on domestic enterprises in Bulgaria. In other studies, no effect of FDI on labour productivity of domestic enterprises was found. These include research of Haddad and Harrison (1993) for Morocco; Djankov and Bernard (2000) for the Czech Republic; Konings (2001) for Bulgaria; Huang (2004), Cheung and Lin (2004), and Liu, Parker, and Wei (2001) for China.

In the research by Bin Ni, Manole, Otsuki, and Yamada (2017) for Vietnam, panel data from 2002 to 2011 are used to examine the effect of technology spillovers of FDI on the labour productivity of domestic enterprises. That study concluded that the labour productivity of Vietnam's enterprises with vertical linkages was found to increase if the investors were from ASEAN countries and remain unchanged in the case of European and North American investors. In ASEAN region, the effects of the investing partners China and Taiwan are most significant. Horizontal linkages are likely negative, as domestic enterprises may be over supported by intra-industrial MNEs.

\subsection{The Relationship between Labour Productivity and Human Capital}

The concept of human capital became popular in the 1960s with research of Mincer (1958), Schultz (1961) and Machlup (1962). Accordingly, human capital was viewed from an individual's perspective and was considered an asset. In production, Schultz (1961) believed that the productive capacity of human beings was vastly larger than all other forms of wealth taken together. Sheffrin (2003) later defined human capital as "the stock of skills and knowledge embodied in the ability to perform labor so as to produce economic value". Rodriguez and Loomis (2007) suggested that human capital included knowledge, skills, abilities and characteristics that facilitate creating benefits for each individual, the society and the whole economy.

Mankiw, Romer, and Weil (1992) found evidence indicating that production of a country increased with increasing number of people in the workforce and workers with higher than secondary education. Most empirical research pointed out that if appropriate healthcare and education were given to the labour force, the production would be higher. This conclusion is backed by research of Khan, Amjad, and Din (2005) and Afridi (2016) for Pakistan; Benos and Karagiannis (2016) for Greece; Tsai, Hung, and Harriott (2010) and Li and Wang (2018) for China.

However, the effects of FDI and human capital on labour productivity in this empirical research are still concluded ambiguously. Benhabib and Spiegel (1994), Engelbrecht (1997), and Frantzen (2000) found the effect of FDI, yet found no effect of human capital on labour productivity. Explaining this result, the authors claimed that there were a significant gap in quality between workers in MNEs and those in domestic enterprises. The quality of human capital can not be improved in the short term. Moreover, compared to domestic enterprises, benefits in MNEs are often better. As a result, professional workers tend to move to MNEs. This slows the improvement of labour productivity in domestic enterprises, as well as the social total labour productivity.

\section{Data and Research Methods}

\subsection{Research Model}

According to the endogenous theory of Romer (1990), Cobb-Douglas production function is illustrated as follows: $Y$ 
$=A \cdot K^{\alpha} \cdot L^{\beta} \cdot T^{\lambda}$. Note: $Y$ is total output, $A$ is total factor productivity, $\mathrm{K}$ is capital input, $\mathrm{L}$ is labour input, $\mathrm{T}$ represents technology. As outlined in the literature review, this paper aims at assessing the effects of FDI and human capital on the labour productivity of Vietnam's economy. Based on previous research of Egger and Pfaffermayr (2001); Hale and Long (2011); Bin Ni et al. (2017), the authors propose research model as follows:

$$
L n P_{t}=\frac{L n Y_{t}}{L n L_{t}}=\beta_{0}+\beta_{1} L n F \mathrm{D} I_{t}+\beta_{2} \cdot H \mathrm{DI} I_{t}+\beta_{3} \cdot\left(H \mathrm{DI} I_{t} \cdot F \mathrm{DI} I_{t}\right)+u_{t}
$$

(Equation 1)

LnP is logarithm of productivity per capita (at fixed price 2011), LnFDI is logarithm of FDI per capita, and HDI is index of human capital per person. The data were collected from UNCTAD, FRED in the 1986-2014 period. If $\beta_{3}$ coefficients are positive, it implies that better quality of human capital means Vietnam can attract more FDI projects with advanced technology and better improve labour productivity.

\subsection{Data and Method}

According to Engle and Granger (1987) and Omri, Nguyen, and Rault (2014), the data of economic growth, labour productivity and FDI were often sustained data. In other words, the economic growth rate of the current year would be affected by those of previous years. Thus, lagged values of dependent variables became explanatory variables for the current year. This problem in the model cannot be solved by the Ordinary Least Square (OLS) technique. Hence in this paper, the Autoregressive Distributed Lags (ARDL) technique introduced by Pesaran, Shin, and Smith (2001) was applied.

Model 1 is illustrated with ARDL as follows:

$$
\begin{aligned}
& \Delta L n P_{t}=\beta_{0}+\beta_{1} \cdot \operatorname{LnP}_{t-1}+\beta_{2} \cdot \operatorname{LnFDI}_{t-1}+\beta_{3} \cdot \operatorname{HDI}_{t-1}+\beta_{4} \cdot\left(F \mathrm{FDI} I_{t-1} \cdot\left(H D I_{t-1}\right)\right. \\
& +\sum_{i=1}^{m 1} \beta_{5 i} \cdot \Delta L n P_{t-i}+\sum_{i=0}^{m 2} \beta_{6 i} \cdot \Delta L n F D I_{t-i}+\sum_{i=0}^{m 3} \beta_{7 i} \cdot \Delta H D I_{t-i}+\sum_{i=0}^{m 4} \beta_{8 i} \cdot\left(F D I_{t-i} \cdot H D I_{t-i}\right)+\mu_{t}
\end{aligned}
$$

(Equation 2)

Note: $\Delta$ : difference

$\beta_{1}, \beta_{2}, \beta_{3}, \beta_{4}$ are regression coefficients that present longterm effects

$\beta_{5}, \beta_{6}, \beta_{7}, \beta_{8}$ are regression coefficients that present shortterm effects

$\mu_{t}$ is random error

When estimating Eq.2, it was necessary to run cointegration test to check if there was a long-term relationship between variables. If there was a long-term cointegrated relationship, estimation of Eq.2 would be examined with the Error Correction Model (ECM) based on this equation:

$$
\Delta L P_{t}=\beta_{0}+\alpha \cdot E C M_{t-1}+\sum_{i=1}^{m 1} \lambda_{i i} \cdot \Delta n P_{t-i}+\sum_{i=0}^{m 2} \lambda_{i i} \cdot N L F D I_{t-i}+\sum_{i=0}^{m 3} \lambda_{i i} \cdot H D I_{t-i}+\sum_{i=0}^{m 4} \lambda_{i i}\left(F D I_{t-i} \cdot H D I_{t-i}\right)+\tau_{t}
$$

(Equation 3)

Note: $m_{1}, m_{2}, m_{3}, m_{4}$ are lag lengths corresponding to each variable, calculated by ARDL model following AIC, SC, HQ criteria and adjusted R-squared. In Eq.3, if there exists $\alpha$ in which $\alpha \neq 0$ and $\alpha$ is statistically significant, $\alpha$ represents the speed at which GDP per capita adjusts to long-run equilibrium after each short-run shock. Besides, before estimation results were applied to prediction, the stability of the model would be ensured with Cumulative Sum of Recursive Residuals (CUSUM) and Cumulative Sum of Square Recursive Residuals (CUSUMSQ).

Instead of traditional Granger causality test, the modified Wald (MWALD) proposed by Toda and Yamamoto (1995) was used to examine the causal relationships between variables. Toda and Yamamoto (1995) examined variables at level using the Vector Autoregression (VAR) model. VAR model illustration of 3 variables $L n P$, LnFDI and $H D I$ :

$$
\begin{aligned}
& \operatorname{LnP} P_{t}=\alpha_{0}+\sum_{i=1}^{k} \alpha_{1 i} \operatorname{Ln} P_{t-i}+\sum_{j=k+1}^{h} \alpha_{21} L n P_{t-j}+\sum_{i=1}^{k} \delta_{1 i} L n F \mathrm{DI} I_{t-i}+\sum_{j=k+1}^{h} \delta_{2 i} L n F \mathrm{DI} I_{t-j} \\
& +\sum_{i=1}^{k} \theta_{1 i} H \mathrm{DD} I_{t-i}+\sum_{j=k+1}^{h} \theta_{2 i} H \mathrm{DI} I_{t-j}+\mu_{1 t}
\end{aligned}
$$

(Equation 4)

$$
\begin{aligned}
& \operatorname{LnFDI} I_{t}=\beta_{0}+\sum_{i=1}^{k} \beta_{1 i} L n F D I_{t-i}+\sum_{j=k+1}^{h} \beta_{2 i} L n F D I_{t-j}+\sum_{i=1}^{k} \theta_{1 i} H D I_{t-i}+\sum_{j=k+1}^{h} \theta_{2 i} H D I_{t-j}+ \\
& +\sum_{i=1}^{k} \alpha_{1 i} L n P_{t-i}+\sum_{j=k+1}^{h} \alpha_{2 i} L n P_{t-j}+\mu_{2 t}
\end{aligned}
$$

(Equation 5)

$$
\begin{aligned}
& H \mathrm{D} I_{t}=\gamma_{0}+\sum_{i=1}^{k} \gamma_{1 i} H \mathrm{DD} I_{t-i}+\sum_{j=k+1}^{h} \gamma_{2 i} H \mathrm{DI} I_{t-j}+\sum_{i=1}^{k} \delta_{1 i} L n F \mathrm{DI} I_{t-i}+\sum_{j=k+1}^{h} \delta_{2 i} L n F \mathrm{DI} I_{t-j}+ \\
& +\sum_{i=1}^{k} \alpha_{1 i} L n P_{t-i}+\sum_{j=k+1}^{h} \alpha_{2 i} L n P_{t-j}+\mu_{3 t}
\end{aligned}
$$

(Equation 6)

Note: $k$ is VAR model lag length chosen following AIC, SC, HQ criteria, $h=\left(k+d_{\max }\right)$ with $d_{\max }$ is the maximum integrated order of series, obtained from the stationarity test of variables. In Eq.4, LnFDI was causal to $\mathrm{LnP}$ if $\delta_{1 i} \neq 0 \forall \mathrm{i}$; the same applied to Eq.5 and Eq.6. According to Mavrotas and Kelly (2001), Toda \& Yamamoto method minimized the risk of inaccurate determination of each variable's integrated order. It could be applied whether that variable was stationary at I(0) or I(1), cointegrated or non-cointegrated. 


\section{Research Results and Discussion}

\subsection{Descriptive Statistics}

Vietnam continues to attract FDI and significantly increase in GDP per capita. Vietnam's economy is transforming from a resource-based a more technology-based growth strategy. In 2015, labour productivity per capita of Vietnam reached US\$10,493, and FDI committed value was US\$ 14.2 billion. Human capital index were gradually improved. Descriptive statistics of variables in the models are shown in Table 1.

Table 1: Descriptive statistics of variables

\begin{tabular}{|c|c|c|c|c|}
\hline Variable & Mean & Maximum & Minimum & Std.Error \\
\hline LnP & 8.634 & 9.258 & 8.045 & 0.381 \\
\hline LnFDI & 2.464 & 4.838 & -7.353 & 2.703 \\
\hline HDI & 2.067 & 2.670 & 1.696 & 0.315 \\
\hline
\end{tabular}

\subsection{Empirical Results}

\subsubsection{Results of Stationarity Test}

It is well documented in the existing time series econometric literature that regression results may be spurious if the estimated variables are non-stationary and/or not cointegrated. In light of this, testing for a unit root of each series is necessary. Two common methods testing stationarity: Augmented Dickey and Fuller (1981) test and Phillip and Perron (1988) test were performed to ensure validity of results. Results of stationarity test are shown in Table 2.

Results in Table 2, shown LnFDI and HDI variables were stationary at level, LnP, (FDI.HDI) at first difference and no variables at second difference. Hence, the conditions to apply the Autoregressive Distributed Lags (ARDL) of Pesaran et al. (2001) are satisfied.

Table 2: Stationarity test results

\begin{tabular}{|l|c|c|}
\hline \multicolumn{1}{|c|}{ Variables } & ADF test & Phillip \& Perron test \\
\hline $\mathrm{LnP}$ & -2.058 & -2.305 \\
\hline$\Delta \mathrm{LnP}$ & $-3.629^{* *}$ & $-3.418^{*}$ \\
\hline $\mathrm{LnFDI}$ & $-6.323^{* * *}$ & $-5.571^{* * *}$ \\
\hline$\Delta \mathrm{LnFDI}$ & $-9,001^{* * *}$ & $-9.063^{* * *}$ \\
\hline $\mathrm{HDI}$ & $-4.006^{* *}$ & $-22.27^{* * *}$ \\
\hline$\Delta \mathrm{HDI}$ & -2.308 & -1.984 \\
\hline (FDI.HDI) & -1.131 & -1.222 \\
\hline$\Delta(\mathrm{FDI} . \mathrm{HDI})$ & $-4.194^{* *}$ & $-3.969^{* *}$ \\
\hline
\end{tabular}

***, ${ }^{* *}$ and ${ }^{*}$ respectively denote significance levels of $1 \% ; 5 \%$ and $10 \%$. Determination of optimal lag length

In ARDL model, identification of optimal lag length is important. Optimal lag lengths are recognised by ARDL model based on initial number of lagged lengths, which is 4 . According to AIC, SC and $\mathrm{HC}$ criteria, the optimal lag length of the model is equal to 1 . As the highest level of stationarity was 1, the optimal ARDL model for our data is $\operatorname{ARDL}(3,2,2$, 2) according to AIC, SC and HC criteria. Then, in Eq.2, $\mathrm{m}_{1}=$ 3 and $m_{2}=m_{3}=m_{4}=2$.

\subsubsection{Results of Cointegration Test}

According to the examination of Engle and Granger (1987) on series data, there might be long-term cointegrations between variables. The technique to examine cointegration in ARDL model introduced by Pesaran et al. (2001) is called the Bound Test. Table 3 showed that F-statistic is equal to $4.454>$ upper bound is equal to 3.67 at the significance level of $5 \%$. Results of the bound test revealed that there were long-term cointegrations between LnP, LnFDI, HDI and (HDI.FDI). Then Eq.2 should be estimated with the Error Correction Model.

Table 3: Results of cointegration test

\begin{tabular}{|c|c|c|c|c|}
\hline \multicolumn{2}{|c|}{ F-Bounds Test } & \multicolumn{4}{c|}{ Null Hypothesis: No level relationship } \\
\hline Test statistic & Value & Signif & $\mathrm{I}(0)$ & $\mathrm{I}(1)$ \\
\hline F-statistic & 4.454 & $10 \%$ & 2.37 & 3.2 \\
\hline $\mathrm{k}$ & 3 & $5 \%$ & 2.79 & 3.67 \\
\hline & & $2.5 \%$ & 3.15 & 4.08 \\
\hline & & $1 \%$ & 3.65 & 4.66 \\
\hline
\end{tabular}

\subsubsection{The Error Correction Model and Short-term Effects}

Variables were stationary at different levels, and there were long-term cointegrations between variables in the model. Thus, Eq.2 was estimated with the Error Correction Model to determine short-term effect coefficients. Results of short-term effect of FDI, human capital and labour productivity in Vietnam in the 1986-2014 period are illustrated in Table 4.

Table 4: Results of estimation with the Error Correction Model

\begin{tabular}{|c|c|c|c|c|}
\hline Variable & Coefficient & Std. Error & t-statistic & Prob \\
\hline$\Delta . \mathrm{LnP}(-1)$ & 0.191315 & 0.167129 & 1.144715 & 0.2715 \\
\hline$\Delta . \mathrm{LnP}(-2)$ & -0.333232 & 0.150792 & -2.209880 & 0.0443 \\
\hline$\Delta . \mathrm{LnFDI}$ & 0.003349 & 0.003347 & 1.000689 & 0.3340 \\
\hline$\Delta$ LnFDI(-1) & -0.019227 & 0.007279 & -2.641528 & 0.0193 \\
\hline$\Delta . \mathrm{HDI}$ & 0.585203 & 0.450706 & 1.298413 & 0.2151 \\
\hline$\Delta . \mathrm{HDI}(-1)$ & -1.645114 & 0.547205 & -3.006393 & 0.0094 \\
\hline$\Delta .(\mathrm{FDI} . \mathrm{HDI})$ & -0.000193 & $8.28 \mathrm{E}-05$ & -2.326150 & 0.0355 \\
\hline$\Delta(\mathrm{FDI} . \mathrm{HDI}(-1))$ & 0.000297 & 0.000111 & 2.673252 & 0.0182 \\
\hline ECM(-1) & -0.250053 & 0.046728 & -5.351270 & 0.0001 \\
\hline
\end{tabular}

Estimated results showed that $\alpha=-0,25$ at the $1 \%$ significance level. This implied that labour productivity per 
capita was able to adjust to long-run equilibrium after each short-run shock as affected by FDI and human capital. The time needed for adjustment was rather long, approximately 4 years $(=1 /(-\alpha))$. $\beta$ coefficients of LnFDI and HDI were positive, but not yet significance, implying that in the short term, both FDI and human capital has no effects on labour productivity.

\subsubsection{Additional tests}

To ensure that estimation results obtained were reliable, possible defects of the model were examined through: Heteroscedasticity test, autocorrelation test and normal distribution of residuals test. According to results in Table 5, heteroscedasticity and autocorrelation were not found in the model, and residuals were normally distributed. Hence, the conditions of the classic regression model were satisfied in Eq.1.

Table 5: Diagnostic tests

\begin{tabular}{|l|c|}
\hline \multicolumn{1}{|c|}{ Type of test } & Equation 2 \\
\hline \multicolumn{1}{|c|}{ Value } & Obs * $\mathrm{R}$ square \\
\hline Test of Heteroskedasticity (White test) & $15.193($ Prob $=0.2310)$ \\
\hline $\begin{array}{l}\text { Test of Serial correlation } \\
\text { (Breusch-Godfrey test) }\end{array}$ & 4.7926 (Prob $=0.0911)$ \\
\hline Test of Histogram (Normality test) & $0.3379($ Prob $=0.8445)$ \\
\hline
\end{tabular}

\subsubsection{Stability Test}

Next, the stability of Eq.2 was ensured with the Cumulative Sum of Recursive Residuals (CUSUM) and the Cumulative Sum of Squares of Recursive Residuals (CUSUMSQ) tests. Figure 1 showed that both CUSUM và CUSUMSQ lines (solid lines) of Eq.2 were within the critical bounds at the significant level of $5 \%$ (dashed lines). Thus it could be concluded that Eq.2 was stable, and the estimated results were reliable for further analysis and prediction.

\subsubsection{Results of Long-term Effects}

To identify the direction of effect and the level of effect of FDI and human capital on the labour productivity of Vietnam in the 1986-2014 period, long-term effect was estimated. Results in Table 6 show that LnFDI has positive effect at the significance level of $5 \%$ on labour productivity. If other conditions remained unchanged, an $1 \%$ increase in FDI would boost labour productivity by $0.111 \%$. HDI coefficient is positive at the significance level of $1 \%$, which means human capital has significant effect on labour productivity. (FDI.HDI) coefficient is negative at the significance level of $1 \%$. As an implication, FDI projects in Vietnam mostly aim at exploiting natural resources and low-cost labour.

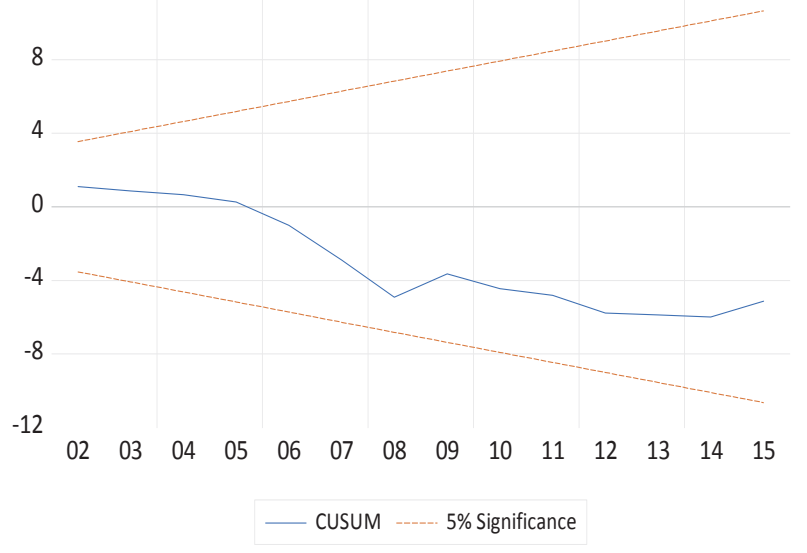

1.6

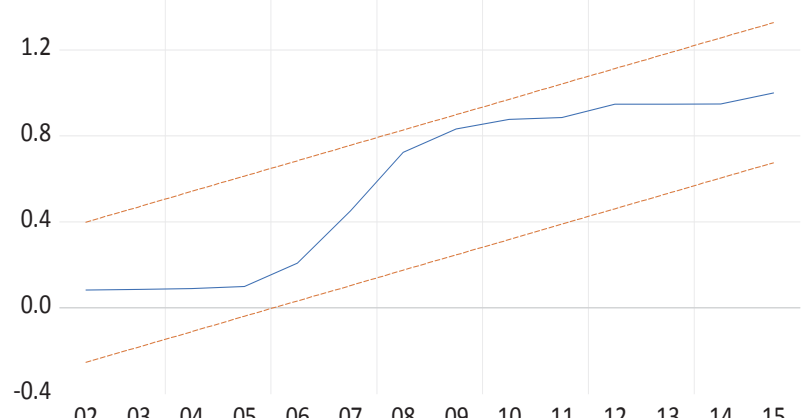

$\begin{array}{llllllllllllll}02 & 03 & 04 & 05 & 06 & 07 & 08 & 09 & 10 & 11 & 12 & 13 & 14 & 15\end{array}$

__ CUSUM of Squares _-__. $5 \%$ Significance

Figure 1: Results of stability test

Table 6: Estimated results of long-term effects

\begin{tabular}{|c|c|c|c|c|}
\hline Variables & Coefficient & Std. Error & t-statistic & Prob \\
\hline LnFDI & 0.111 & 0.041 & 2.698 & 0.017 \\
\hline HDI & 1.397 & 0.196 & 7.141 & 0.000 \\
\hline FDI.HDI & -0.002 & 0.001 & -3.143 & 0.007 \\
\hline Intercept & 5.957 & 0.316 & 18.87 & 0.000 \\
\hline ECM = LnP- (0.111*LnFDI + 1.397*HDI - 0.002*FDI.HDI + 5.957) \\
\hline
\end{tabular}

The Granger causality relationships between variables are examined using the method of Toda and Yamamoto (1995) with null hypothesis does not Granger cause. Granger causalities between variables of Eq.2 are illustrated in Figure 2. There is uni-directional Granger causality running from FDI, HDI, (FDI.HDI) to labour productivity. There is bi-directional Granger causality running from FDI to (FDI.HDI). No causality between foreign direct investment and index of human capital per person (Figure 2). 


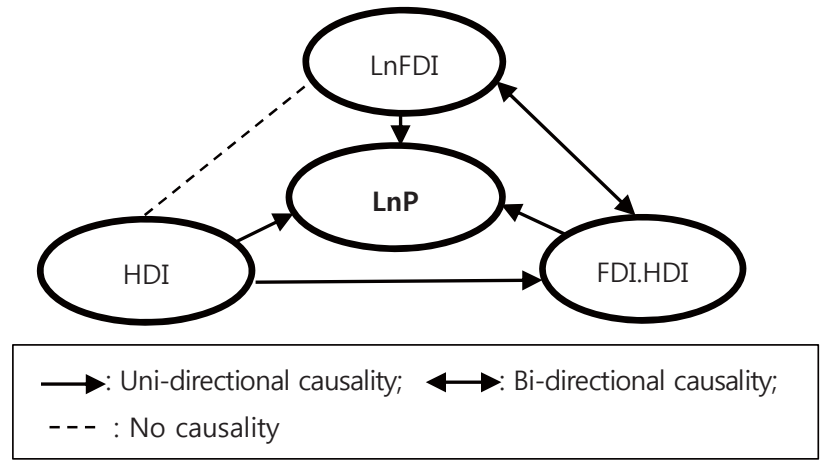

Figure 2: Granger causalities between variables

\section{Conclusions and Policy Implications}

With the data of the 1986-2014 period, the Autoregressive Distributed Lag model of Pesaran et al. (2001) and the Granger causality test with the method of Toda and Yamamoto (1995), article affirms these two following main points:

(i) FDI and human capital have positive effect on improving labour productivity in the long term.

(ii) There is uni-directional Granger causality running from FDI and index of human capital to labour productivity.

Based on empirical results, the policy implications are proposed as follows:

Firstly, Vietnam should promote tertiary education socialisation and vocational education. The low labour productivity of Vietnam is mainly due to the relatively poor quality of the workforce. Results reveal that labour productivity is positively affected by human capital, implying that more investments should be directed to education and training. It is also necessary to develop the quality of educators, to standardise the courses according to international standards, and to link theoretical education to the reality.

Secondly, there should be long-term strategies to attract FDI. Priority should be given to high-tech FDI projects that use less natural resources. Also, incentives should be directed to FDI projects that carry out transfer of technology, management techniques, or market-expanding support to domestic enterprises.

\section{References}

Afridi, A. H. (2016). Human capital and economic growth of Pakistan. Business \& Economic Review, 8(1), 77-86.

Aitken, B., \& Harrison, A. (1999). Do Domestic Firms Benefit from Direct Foreign Investment? Evidence from Venezuela. American Economic Review, 90, 605-18.
Arrow, K. (1962). The Economic implication of learning-bydoing. Review of Economic Studies, 29(1). 155-173.

Benahabib, J., \& Spiegel, M.M. (1994). The Role of Human Capital in Economic Development Evidence from Aggregate Cross-Country Data. Journal of Monetary Economics, 34, 143-73.

Benos, N., \& Karagiannis, S. (2016). Do education quality and spillovers matter ? Evidence on human capital and productivity in Greece. Economic Modelling, 54, 563-573.

Bin Ni, S. M., Manole, V., Otsuki, T., \& Yamada, H. (2017). The Origin of FDI and Domestic Firms'Productivity Evidence from Vietnam. Journal of Asian Economics, 52, 56-76.

Blomstrom, M., \& Wang, J.Y. (1992). Foreign Investment and Technology Transfer: A Simple Model (NBER Working Paper No. 2958).

Blomstrom, M., \& Kokko, A. (1998). Multinational Corporations and Spillovers. Journal of Economic Surveys, 12(2), 1-31.

Caves, R. E. (1971). International Corporations: The Industrial Economics of Foreign Investment. Economica, 38, 1-27.

Caves, R. E. (1996). Multinational Enterprise and Economic Analysis (2nd Edition). New York, NY: Cambridge University Press.

Chakraborty, C., \& Basu, P. (2002). Foreign direct investment and growth in India: A cointegration approach. Applied Economics, 34, 1061-1073.

Cheung, K-Y., \& Lin, P. (2004). Spillover Effects of FDI on Innovation in China: Evidence from the Provincial Data. China Economic Review, 15, 25-44.

Choe, J. (2003). Do Foreign Direct Investment and Gross Domestic Investment Promote Economic Growth? Review of Development Economics, 7, 44-57.

Dickey, D. A., \& Fuller, W. A. (1981). Likelihood ratio statistics for autoregressive time series with a unit root. Econometrica, 49, 1057-1072.

Djankov, S., \& Bernard, H. (2000). Foreign investment and productivity growth in Czech enterprises. World Bank Economic Review, 14(1), 49-64.

Domar, E. D. (1946). Capital expansion, rate of growth and employment. Econometrica, 14, 137-147

Egger, P., \& Pfaffermayr, M. (2001). A note on labour productivity and foreign inward direct investment. Applied Economics Letters, 8, 229-232.

Engelbrecht, H. J. (1997). International R\&D spillovers, human capital and productivity in OECD economies: An empirical investigation. European Economic Review, 41, 1479-1488.

Engelbrecht, H. J. (2002) Human capital and international knowledge spillovers in TFP growth of a sample of 
developing countries: An exploration of alternative approaches. Applied Economic, 34, 831-841.

Engle, R. F., \& Granger, C. W. J. (1987). Co-integration and Error Correction: Representation, Estimation and Testing. Econometrica, 55, 251-276.

Frankel, M. (1962). The Production Function in Allocation of Growth: A Synthesis. American Economic Review, 52, 995-1022.

Frantzen, D. (2000). R\&D, human capital and international technology spillovers: A cross-country analysis. The Scandinavian Journal of Economics, 102, 57-75.

Globerman, S. (1979). Foreign Direct Investment and 'Spillover' Efficiency Benefits in Canadian Manufacturing Industries. Canadian Journal of Economics, 12(1), 35-46.

Haddad, M., \& Harrison, A. (1993). Are there positive spillovers from direct foreign investment? Journal of Development Economics, 42, 51-74.

Hale, G., \& Long, C. (2011). Are there productivity spillovers from foreign direct investment in China? Pacific Economic Review, 16(2), 135-153.

Harrod, R. F. (1939). An essay in dynamic theory. The Economic Journal, 49, 14-33.

Huang, J-T. (2004). Spillovers from Taiwan, Hong Kong, and Macau Investment and from Other Foreign Investment in Chinese Industries. Contemporary Economic Policy, 22, 13-25.

Javorcik, B. S. (2004). Does Foreign Direct Investment Increase the Productivity of Domestic Firms? In Search of Spillovers through Backward Linkages. American Economic Review, 93, 605-27.

Khan, M. S., Amjad, R., \& Din, M. U. (2005). Human capital and Economic growth in Pakistan. The Pakistan Development Review, 455-478.

Konings, J. (2001). The effects of foreign direct investment on domestic firms. Economics of Transition, 9(3), 619-633.

Krueger, A. B., \& Lindahl, M. (2001). Education for Growth: Why and For Whom? Journal of Economic Literature, 39, 1101-36.

Li, T., \& Wang, Y. (2018). Growth channels of human capital: A Chinese panel data study. China Economic Review, 51, 309-322.

Liu, X., Parker, K. V., \& Wei, Y. (2001). The Impact of Foreign Direct Investment on Labour Productivity in the Chinese Electronics Industry. International Business Review, 10, 421-39.

Machlup, F. (1962). The production and distribution of knowledge in the United States. Princeton, NJ: Princeton University Press.

Mankiw, N. G., Romer, D., \& Weil, D. N. (1992). A contribution to the empirics of economic growth. The Quarterly Journal of Economics, 107(2), 407-437.
Markusen, J. R., \& Venables, A. J. (1999). Foreign direct investment as a catalyst for industrial development. European Economic Review, 43, 335-356.

Mavrotas, G., \& Kelly, G. (2001). Old wine in new bottles: Testing causality between savings and growth. Manchester School, 69(1), 97-105.

Mincer, J. (1958). Investment in human capital and personal income distribution. The Journal of Political Economy, 66(4), 281-302.

Monastiriotis, V., \& Alegria, R. (2011). Origin of FDI and intra-industry domestic spillovers: The case of Greek and European FDI in Bulgaria. Review of Development Economics, 15(2), 326-339.

Nowbutsing, B. (2009). FDI Domestic Investment and Economic Growth: A Theoretical Framework. Port Louis, Mauritius: University of Technology Mauritius.

Omri, A., Nguyen, D. K., \& Rault, C. (2014). Causal interactions between $\mathrm{CO}_{2}$ emissions, $\mathrm{FDI}$, and economic growth: Evidence from dynamic simultaneous-equation models. Economic Modelling, 42, 382-389.

Pesaran, M. H., Shin, Y., \& Smith, R. J. (2001). Bounds testing approaches to the analysis of level relationships. Journal of Applied Econometrics, 16(3), 289-326.

Phillips, P. C. B., \& Perron, P. (1988). Testing for a unit root in time series regression. Biomètrika, 75(2), 335-346.

Rodriguez, J. P., \& Loomis, S. R. (2007). A new view of institutions, human capital, and market standardisation. Education, Knowledge \& Economy, 1(1), 93-105.

Romer P. M. (1986). Increasing Returns and Long Run Growth. Journal of Political Economy, 94, 1002-1037.

Romer, D., \& Frankel, J. A. (1999). Does Trade Growth Cause Growth? American Economic Review, 8(3), 379399.

Romer, P. M. (1990). Endogenous Technological Change. Journal of Political Economy, 98, 71-102.

Schoors, K., \& Van der Tol, B. (2001, October). The productivity effect of foreign ownership on domestic firms in Hungary. International Atlantic Economic Conference in Philadelphia, 11-14.

Schultz, T. W. (1961). Investment in human capital. American Economic Review, 51(1), 1-17.

Sheffrin, M. S. (2003). Economics: Principles in Action. Upper Saddle River, NJ: Pearson Prentice Hall.

Toda, H. Y., \& Yamamoto, T. (1995). Statistical inference in vector autoregressive with possibly integrated processes. Journal of Econometrics, 66(1), 225-250.

Tsai, C. L., Hung, M. C., \& Harriott, K. (2010). Human capital composition and economic growth. Social Indicators Research, 99(1), 41-5 